DOI: 10.20472/IAC.2018.038.044

\author{
LIXIA YAO
}

Energy Studies Institute, National University of Singapore, Singapore

\title{
BELT AND ROAD INITIATIVE IN SOUTHEAST ASIA'S ENERGY SECTOR: IMPACTS AND IMPLICATIONS FOR THE REGION
}

\begin{abstract}
:
The Belt and Road Initiative (BRI hereafter) is an enormous infrastructure initiative first announced by Chinese President Xi Jinping in 2013. It is the largest infrastructure initiative ever. Investment will be directed to roads, railways and ports, as well as energy infrastructure including coal plants, pipelines, transmission lines and renewable energy projects. This study focuses on energy infrastructure investment in Southeast Asia. First it briefly reviews (with data) the current energy security situation and concerns in Southeast Asia; second, it discusses new Chinese investment in energy infrastructure in Southeast Asia since BRI was initiated; third, it analyzes its impact on energy capacity increment and energy infrastructure connection in the region; lastly, the study looks at how the Chinese investment can help or hinder the energy market integration in Southeast Asia and the potential role of Singapore against the context of BRI in Southeast Asia's energy sector.
\end{abstract}

\section{Keywords:}

The Belt and Road Initiative; Southeast Asia; Energy investment 